\title{
EVALUATING THE EFFECTS OF WETLAND REGULATION THROUGH HYDROGEOMORPHIC CLASSIFICATION AND LANDSCAPE PROFILES
}

\author{
Stephanie E. Gwin', Mary E. Kentula ${ }^{2}$, and Paul W. Shaffer ${ }^{1}$ \\ 'Dynamac Corporation Environmental Services \\ $200 \mathrm{SW} 35^{\text {th }}$ Street \\ Corvallis, Oregon, USA 97333 \\ 2 United States Environmental Protection Agency, NHEERL-WED \\ $200 \mathrm{SW} 35^{\text {th }}$ Street \\ Corvallis, Oregon, USA 97333
}

\begin{abstract}
Landscape profiles describing the pattern of the diversity of wetlands in a region can serve as a standard for characterizing the resource and quantifying the effects of management decisions. We used hydrogeomorphic (HGM) classification to generate landscape profiles to evaluate the effects of mitigation in the rapidly urbanizing area of Portland, Oregon, USA. The profiles were produced from information on the types, numbers, and relative abundances of wetlands by HGM class. Using field data, topographic maps, and National Wetland Inventory maps, we classified 45 naturally occurring wetlands (NOWs) into regional HGM classes (depression, riverine, slope, and lacustrine fringe) and developed the corresponding landscape profile (the NOW-Profile). We then classified 51 mitigation wetlands (MWs) and added them to the profile (the All Site-Profile) to examine changes in the regional wetland resource. The classification of MWs required development of new, atypical HGM classes to describe the unique combinations of site morphology and landscape setting found in these wetlands: depression-in-riverine-setting, in-stream-depression, and depression-in-slope-setting. Comparison of the landscape profiles showed that the structure and settings of NOWs and MWs are very different. Most NOWs fell into the regional HGM classes ( $91 \%)$, but most MWs fit the atypical classes (75\%). Most NOWs were riverine wetlands (56\%), whereas most MWs were depressionsin-riverine-setting and in-stream-depressions (33\% for each class). The All Site-Profile showed an increase in the proportion of wetlands with depressional morphology, comprised mostly of MWs. Results also showed that the majority (71\%) of MWs were constructed, at least partially, within existing NOWs through an exchange of wetland types and that most of these MWs (86\%) belonged to the atypical classes. The approach used shows that the cumulative effects of wetland management decisions can be discerned effectively through HGM classification and development of landscape profiles. Although our results are important in documenting the landscape changes taking place in a specific region through mitigation, our approach is generally applicable for evaluating wetland management decisions and helping resource managers to make betterinformed, broad-based decisions about the wetland resource.
\end{abstract}

Key Words: mitigation, wetland creation, wetland enhancement, wetland restoration, Oregon, hydrogeomorphic (HGM) classification, landscape analysis

\section{INTRODUCTION}

A growing number of scientists recommend taking a landscape perspective in resource management in general (e.g., Forman and Godron 1986) and in wetland management, specifically (e.g., Lee and Gosselink 1988, Kentula et al. 1992a, Holland et al. 1995, National Research Council (NRC) 1995, Bedford 1996, Race and Fonseca 1996, Findlay and Houlahan 1997). Landscape approaches are especially useful for assessing the cumulative effects of wetland loss and degradation (Bedford and Preston 1988, Gosselink and Lee 1989, Gibbs 1993). and for evaluating the effectiveness of resource management (Kentula et al. 1992a, Findlay and Houlahan 1997). Decisions about the fate of wetlands in an area have routinely been made on a sitespecific basis only (Lee and Gosselink 1988, Holland et al. 1995. Findlay and Houlahan 1997), with the result that cumulative impacts have not been considered (Bedford 1996, Abbruzzese and Leibowitz 1997). Therefore, impacts to the overall wetland resource, usually undetectable at the site level, have gone unnoticed.

We present an approach for identifying the potential for regional ecological effects from wetland loss and regulatory decisions using data from wetlands in the 
rapidly urbanizing area of Portland, Oregon, USA. We employ the principles of hydrologic equivalence and wetland templates as defined by Bedford (1996) and the hydrogeomorphic (HGM) classification of wetlands developed by Brinson (1993) and Smith et al. (1995). The approach is readily applicable to a variety of management and assessment purposes. In this case study, we focus on changes in wetland resources resulting from regulatory decisions made under Section 404 of the U.S. Clean Water Act.

Our work in Portland over the last 10 years has indicated that regulatory decisions stemming from urbanization are resulting in changes in the relative abundances of wetland types as defined by Cowardin et al. (1979) (Kentula et al. 1992b, Holland et al. 1995). Urbanization affects the wetland resource through both disturbance and loss of wetlands (Holland et al. 1995, Findlay and Houlahan 1997). In addition, decisions made under Section 404, allowing wetland loss and requiring compensation through mitigation (i.e., wetland creation, restoration, and enhancement), are contributing to an increase in palustrine open water wetlands with a corresponding decrease in the abundance of other wetland types (Kentula et al. 1992a,b).

We found that palustrine open water wetlands were required as mitigation for the destruction of wetlands of a variety of types, not only in Oregon, but also in California (Holland and Kentula 1992), Washington (Kentula et al. 1992b), and several southeastern states (Sifneos et al. 1992a,b). Others have found similar results through analysis of Section 404 records (e.g., Owen and Jacobs 1992, Sibbing 1997) and field studies comparing wetlands required as mitigation to 1) wetlands that were to be destroyed (e.g., Owen 1990, Eggers 1992), 2) naturally occurring wetlands (e.g., Confer and Niering 1992, Shaich and Franklin 1995), or 3) reference wetlands (e.g., Cole and Brooks 1999). Shifts to palustrine open water wetland systems appear to be nationwide (Tiner 1984, Dahl and Johnson 1991) and are likely the result of resource managers and regulators making decisions on a case-by-case basis.

The specific ecological effects of increasing the abundance of open water wetlands and decreasing the abundance of other types are unknown. However, because scientists have long inferred links between wetland structure and function (e.g., Kentula et al. 1992a, Winter 1992, Mitsch and Gosselink 1993, NRC 1995. Brinson and Rheinhardt 1996), changing the relative abundance of wetland types is apt to affect the ecological characteristics of the overall wetland resource in the area. If changes are widespread, regional biodiversity is likely to be altered. Replacing drier-end wetlands with open- and deep-water habitats eliminates the functions performed by drier-end wetlands and may increase the potential problems associated with construction of ponds, such as creation of habitat for exotic and nuisance species (Holland et al. 1995, Sibbing 1997). In the Pacific Northwest, for example, the bullfrog (Rana catesbeiana Shaw) is an introduced species that requires perennial open water and that has been associated with predation on, and decline of, several native species of amphibians (Nussbaum et al. 1983, Leonard et al. 1993, Kiesecker and Blaustein 1997, Kupferberg 1997).

The research described above supports the concept that mitigation as currently practiced under Section 404 is changing the structure and function of wetland ecosystems (Kentula et al. 1992a, Bedford 1996). Bedford (1996) proposed that landscape profiles be developed and used to evaluate and predict the potential effects of management decisions on the resource in a region. The profiles quantify the relative abundances of wetlands in classes defined in terms of the hydrogeologic factors that cause specific wetland types to form and that support their function within a landscape (Bedford 1996). Wetlands within a class are assumed to be hydrogeologically and functionally similar and to have functions different from wetlands in other classes. HGM classification (Brinson 1993, Smith et al. 1995) is well-suited for this purpose because HGM relies on a landscape perspective and is built upon the premise that wetland structure and function are the expression of geomorphic setting, water source, and hydrodynamics. Therefore, a landscape profile based on HGM classification can be used to describe the broad pattern of functional diversity of wetlands in a region, which can be used as a regional standard for making and assessing management decisions (Bedford 1996).

\section{METHODS}

This paper uses data from wetlands in the Portland, Oregon metropolitan area to evaluate the utility of landscape profiles (Bedford 1996) generated through HGM classification (Brinson 1993, Smith et al. 1995) to examine the potential for regional changes in wetland function due to regulatory decisions associated with urbanization. Specifically, we examine how mitigation under Section 404 of the Clean Water Act has affected the hydrogeomorphic composition of wetlands in the region. The basic steps in the process were to 1) define regional HGM classes for the naturally occurring wetlands (NOWs) studied, 2) develop a landscape profile for the NOWs (sensu Bedford 1996), 3 ) classify the mitigation wetlands (MWs) studied according to the regional scheme, 4) create a second landscape profile using both the NOWs and the MWs, and 5) compare the profiles to explore reasons for similarities and differences. 


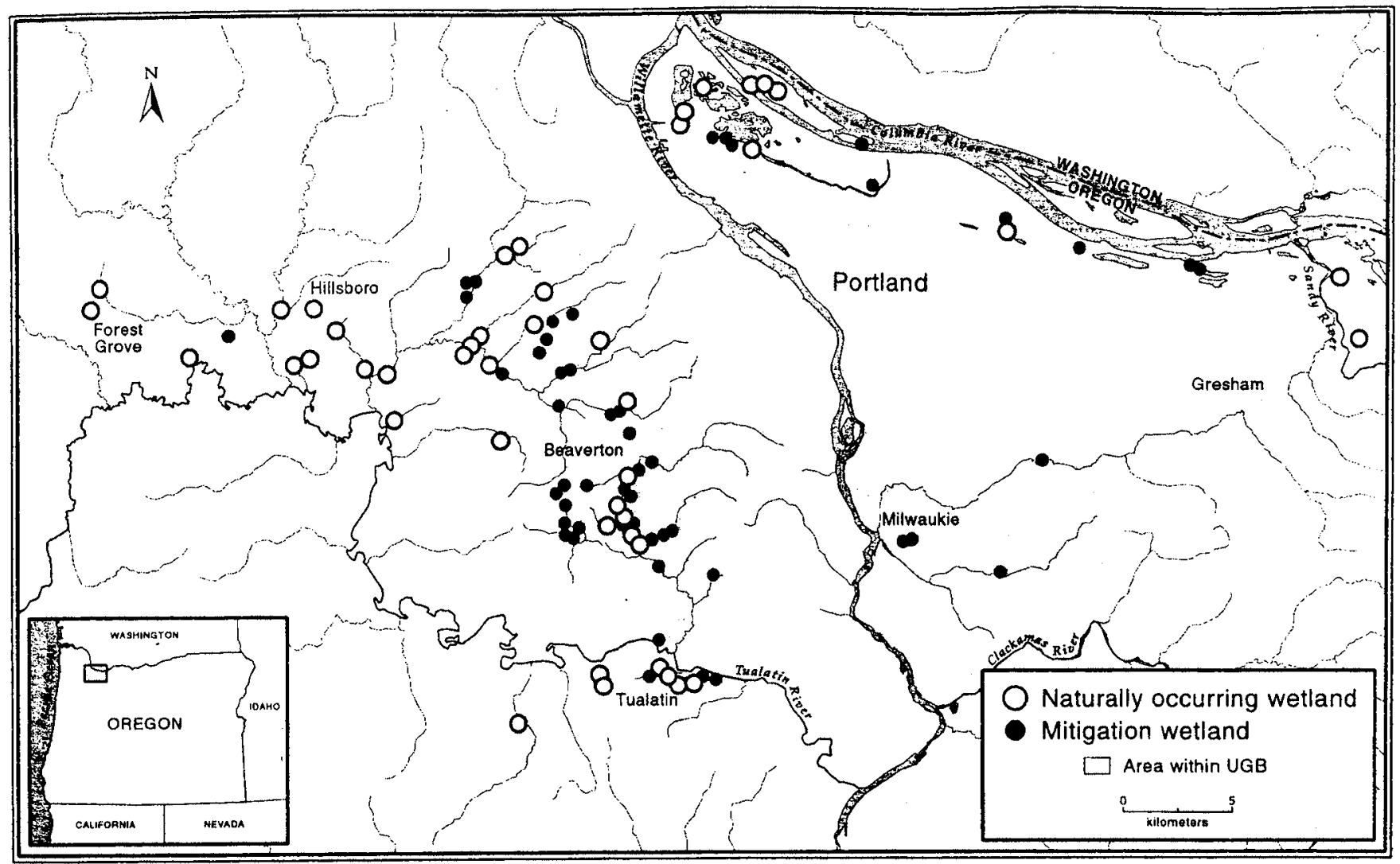

Figure 1. Map of the study area showing locations of naturally occurring and mitigation wetlands, streams, major rivers, and municipalities. Study area is within the Portland, Oregon metropolitan area urban growth boundary (UGB).

\section{Study Area and Site Selection}

The Portland metropolitan area is located in northwestern Oregon at the north end of the Willamette Valley at the confluence of the Columbia and Willamette Rivers. Portland was chosen because rapid development has placed wetlands in the area at high risk for modification and destruction (Holland et al. 1995). The area's population increased by approximately $18 \%$ (over 200,000 people) between 1980 and 1992 (Wineberg 1993), and because of the associated development, a large proportion of the Section 404 permits issued in Oregon and requiring mitigation have involved wetlands in the Portland area (Kentula et al. 1992b).

The study area was defined by a regional framework that considered political boundaries, ecoregions, and hydrologic units (watersheds). The political boundary was defined by Portland's urban growth boundary (UGB), which separates urbanizable from rural land (Oregon Land Use Planning Goal \#14). Inside the UGB, study sites were chosen within the Willamette Valley Plains subregion (Clarke et al. 1991) of the Willamette Valley ecoregion (Omernik 1987). The study area contains portions of the Columbia and Willamette
River basins and much of the Tualatin River watershed (Figure 1).

The wetlands studied were small ( $\leq 2 \mathrm{ha}$ ), palustrine wetlands ranging from those dominated by emergent marsh to those dominated by open water (Cowardin et al. 1979). We sampled 96 wetlands in summer 1993, of which 45 were NOWs and 51 were MWs (Figure 1). This group of wetlands was chosen because it represents the type of NOWs most commonly lost through the Section 404 permitting process in the Portland area and in the State of Oregon (Kentula et al. 1992a,b) and the type most common historically in the Willamette Valley (Davis 1995, Guard 1995). The group also includes the type of MWs most frequently required as mitigation for permitted losses of freshwater wetlands in the Portland area and in the State of Oregon (Kentula et al. 1992a,b).

NOWs were identified from the most recent National Wetland Inventory (NWI) maps (1981 and 1982 aerial photography) and were chosen by a stratified random sample based on proportional representation in five land use classes (undeveloped, agricultural, residential, commercial, and industrial). The final sample of NOWs was almost the entire population of small 
( $\leq 2 \mathrm{ha}$ ), palustrine wetlands dominated by emergent vegetation or open water in the area.

MWs were identified from the permit records of the Oregon Division of State Lands (ODSL), the state agency responsible for permitting the filling or dredging of wetlands and requiring mitigation (Administrative Rules for Oregon's Removal-Fill Permit Program 1986, Oregon Removal-Fill Law 1989, Oregon Wetland Inventory and Wetland Conservation Plans 1989). Records from ODSL included U.S. Army Corps of Engineers Section 404 permits, along with state permits for small or isolated wetlands not covered by Section 404 and specifications for the mitigation projects. All MWs that were palustrine emergent to open water wetlands, $\leq 2$ ha in area and that had been constructed at least one year prior to the scheduled collection of field data were considered for inclusion in the study.

\section{Regional HGM Classes and Landscape Profiles}

Regional HGM classes were defined in terms of the national classes described by Brinson (1993) and Smith et al. (1995) using information about the NOWs in our sample. In developing regional HGM classes, we considered site morphology and location within the landscape, water sources, and hydrodynamics. Information from NWI maps and U.S. Geologic Survey (USGS) topographic maps $(1: 24,000)$ was used to define the landscape setting and identify probable water sources for each NOW. For example, the maps were used to determine if wetlands were located within an active floodplain, on a hillslope, or were isolated from other surface waters.

Field data collected during the summer of 1993 (Magee et al. 1993) were also used to define the regional HGM classes and assign each NOW to a class. The data included site boundaries and morphology, plant species composition and cover, soil characteristics and organic matter content, and the presence and extent of surface water. Photographs were taken and maps were drawn to provide a visual record of the wetland at the time of sampling. Because of the urban nature of the area, many streams have been placed in underground culverts; therefore, we determined each wetland's proximity and relationship to streams currently running underground, as well as those on the surface, using a combination of topographic maps, NWI maps, and site sketches. Lastly, we confirmed any assumptions made about water sources and patterns of flow and finalized HGM assignments after making additional site visits during the winter of 1996/ 1997 and spring of 1997, the wet season in Oregon. Each MW was also assigned to an HGM class using these procedures.

Several landscape profiles were constructed for the study area. Each profile was developed by enumerating the distribution of wetlands among the HGM classes for a different group of wetlands (i.e., NOWs, NOWs and MWs). First, a profile of the 1993 distribution of NOWs (the NOW-Profile) was developed by tallying the number of NOWs in each regional HGM class. A second landscape profile was constructed using 1993 data for both NOWs and MWs (the All Site-Profile). Lastly, two profiles were constructed for MWs from the information available on site conditions before (1981/1982) and after (1993) mitigation activities took place. Site conditions before mitigation were determined from NWI maps based on 1981/1982 aerial photography. Comparisons were made between the various landscape profiles to ascertain if changes in the distribution of regional HGM types had occurred due to regulatory decisions.

\section{Mitigation Method}

We also explored possible explanations for similarities and differences in the profiles by examining the design and siting of MWs (i.e., mitigation method) (Table 1). First, we inspected the Section 404 permit file for each site. Because the text in most permits was imprecise (Gwin and Kentula 1990), we carefully examined available drawings and blueprints for indications of where and how each MW was intended to be built. For example, the boundaries of existing wetlands were often marked on diagrams, as were elevation contour lines, floodplain boundaries, and locations of surface waters.

The permit data indicated that some MWs had been placed within existing wetlands. To verify this, we compared the Cowardin class (Cowardin et al. 1979) assigned to each MW during the 1993 field sampling with the NWI data generated from the 1981/1982 aerial photography. Because the aerial photographs used to create the NWI maps were taken prior to construction of the MWs, if the NWI map indicated the presence of a wetland in a location where an MW currently existed, we reasoned that the MW had been placed within or adjacent to the NOW identified on the NWI map. We then compared the current Cowardin class of the MW to that indicated by the NWI map to determine if the MW was the same type of wetland as had previously existed. We also used the USGS topographic maps to identify which MWs had been placed within pre-existing stream beds and drainageways or within ephemeral streams and examined county soil surveys to determine if the soils in the area were hydric prior to mitigation. Finally, we assigned the mitigation method (Table 1) that best described the process used to produce each MW and verified our determinations through site visits. 
Table 1. Definitions of the methods used to design and site the mitigation wetlands in the study.

\begin{tabular}{|c|c|}
\hline $\begin{array}{c}\text { Mitigation } \\
\text { Method }\end{array}$ & Definition \\
\hline Creation & $\begin{array}{l}\text { Construction of a wetland in an area that was not a wetland in the recent past (within the last } \\
\text { 100-200 years) (Kruczynski 1990, Lewis 1990) and that is isolated from existing wetlands } \\
\text { (i.e., not directly adjacent). Typically, a wetland is created by excavation of upland soils to } \\
\text { elevations that will support the growth of wetland species through the establishment of an ap- } \\
\text { propriate hydroperiod (Kruczynski 1990, Lewis 1990). }\end{array}$ \\
\hline Restoration & $\begin{array}{l}\text { Return of an ecosystem to a close approximation of its condition prior to disturbance (NRC } \\
\text { 1992). Restoration requires knowledge of the wetland type prior to disturbance and has the } \\
\text { goal of returning the wetland to that type. Restoration also may occur when an altered wetland } \\
\text { is returned to a previous, although altered condition (Lewis 1990). }\end{array}$ \\
\hline Enhancement & $\begin{array}{l}\text { Modification of specific structural features of an existing wetland to increase one or more func- } \\
\text { tions based on management objectives, typically done by modifying site elevations or the pro- } \\
\text { portion of open water. Although this term implies gain or improvement, a positive change in } \\
\text { one wetland function may negatively affect other wetland functions (Kruczynski 1990, Lewis } \\
\text { 1990). }\end{array}$ \\
\hline Exchange & $\begin{array}{l}\text { Enhancement taken to the extreme (Kruczynski 1990), with most or all of the wetland converted } \\
\text { from one type of wetland to a different type. For example, resource managers may intend to } \\
\text { enhance habitat value for waterfowl by excavating an area of open water within an existing } \\
\text { emergent marsh. However, if the open water area replaces the emergent wetland or a large } \\
\text { proportion of it, wetland types have been exchanged. }\end{array}$ \\
\hline Expansion & $\begin{array}{l}\text { Enlargement of an existing wetland through the creation (see above) of new wetland area adja- } \\
\text { cent to an existing wetland. Usually, area of the same wetland type is added to the existing } \\
\text { wetland. }\end{array}$ \\
\hline
\end{tabular}

\section{RESULTS}

\section{Regional HGM Classes and Landscape Profiles}

Four regional HGM classes-depression, lacustrine fringe, riverine, and slope-were defined for the naturally occurring wetlands studied using the principles developed by Brinson (1993) and Smith et al. (1995) (Table 2). When we assigned each NOW to a class, four sites could not be classified due to inconsistencies between geomorphic setting and site morphology.

The NOW-Profile shows the 1993 distribution of the 45 NOWs in our sample among the regional HGM classes (Figure 2). Riverine wetlands make up the largest proportion of the NOW-Profile, comprising more than half $(56 \%)$ of the study sites. Wetlands in the slope, depression, and lacustrine fringe classes are much smaller components. This result reflects the spatial distribution of sites within the study area; most NOWs are located along water courses (Figure 1). The distribution of NOWs among the HGM classes in the profile also reflects what is known historically about the relative abundance of wetlands in the Willamette Valley. Although the Valley contained a mosaic of various wetland types prior to European settlement, it was dominated by wet prairies that were associated with systems of braided stream channels (Davis 1995).

\section{Atypical HGM Classes and the All Site-Profile}

The majority of the MWs did not fit the definitions of the regional HGM classes. These MWs had depressional morphology and hydrodynamics but were located in landscape settings characteristic of riverine and slope wetlands. To accurately describe these wetlands, we defined additional regional HGM classes, again using the principles of Brinson (1993) and Smith et al. (1995). Because wetlands in these classes were not typical of wetlands in the NOW-Profile, we refer to them as "atypical" HGM classes. The regional atypical HGM classes are depression-in-riverine-setting, in-stream-depression, and depression-in-slopesetting (Table 3, Figure 3). Identifying features include some combination of the following characteristics, present through human modification of the site: 1) exaggerated depressional morphology characterized by steep banks, often to the angle of repose of the substrate (Figure 3A, B, C); 2) large areas of open, often deep, water (Figure 3A, B, C); 3) a large berm which isolates the wetland from the adjacent stream channel (Figure 3A); and/or 4) excavation within the stream channel resulting in an open water area orders of magnitude wider and deeper than the original stream (Figure 3B).

The All Site-Profile shows the 1993 distribution of 
Table 2. Definitions of regional hydrogeomorphic (HGM) classes of naturally occurring wetlands in the Portland, Oregon metropolitan area. Definitions are based on the principles developed by Brinson (1993) and Smith et al. (1995).

\begin{tabular}{|c|c|c|c|}
\hline HGM Class & Geomorphic Setting & Water Source & Hydrodynamics \\
\hline Depression & $\begin{array}{l}\text { Topographic depression with } \\
\text { closed contours that allow the } \\
\text { accumulation of surface wa- } \\
\text { ters. May have inlets and out- } \\
\text { lets (open depression) or lack } \\
\text { them (closed depression). }\end{array}$ & $\begin{array}{l}\text { Dominant water sources are } \\
\text { precipitation, ground-water } \\
\text { discharge, and overland sur- } \\
\text { face flow from adjacent up- } \\
\text { lands. }\end{array}$ & $\begin{array}{l}\text { Water movement is normally } \\
\text { from surrounding uplands to- } \\
\text { ward the center of the de- } \\
\text { pression. Water levels within } \\
\text { the wetland may fluctuate } \\
\text { with seasonal differences in } \\
\text { precipitation. }\end{array}$ \\
\hline Lacustrine Fringe & $\begin{array}{l}\text { Adjacent to lakes, where the } \\
\text { water elevation of the lake } \\
\text { maintains the water table and } \\
\text { water surface level within the } \\
\text { wetland. }\end{array}$ & $\begin{array}{l}\text { Lake water is the dominant } \\
\text { source; additional sources in- } \\
\text { clude precipitation and } \\
\text { ground-water discharge. }\end{array}$ & $\begin{array}{l}\text { Water movement is bi-direction- } \\
\text { al, controlled by water-level } \\
\text { fluctuations in the adjoining } \\
\text { lake. }\end{array}$ \\
\hline Slope & $\begin{array}{l}\text { Occur on sloping land (may } \\
\text { range from steep hillsides to } \\
\text { nearly flat slopes) where } \\
\text { there is a discharge of ground } \\
\text { water to the land surface. } \\
\text { Surface water cannot accu- } \\
\text { mulate because the wetland } \\
\text { lacks closed contours; may } \\
\text { grade into riverine wetlands } \\
\text { at stream headwaters. }\end{array}$ & $\begin{array}{l}\text { Dominant water sources are } \\
\text { ground water, interflow from } \\
\text { surrounding uplands, and pre- } \\
\text { cipitation. }\end{array}$ & $\begin{array}{l}\text { Water flow is unidirectional } \\
\text { downslope. If channels devel- } \\
\text { op, they serve to convey wa- } \\
\text { ter away from the wetland. }\end{array}$ \\
\hline Riverine & $\begin{array}{l}\text { Occur in floodplains and ripari- } \\
\text { an corridors in association } \\
\text { with a stream or river chan- } \\
\text { nel. }\end{array}$ & $\begin{array}{l}\text { Dominant water sources are } \\
\text { overbank flow and subsurface } \\
\text { hydraulic connections be- } \\
\text { tween the stream and the } \\
\text { wetland. Additional water } \\
\text { sources are precipitation, trib- } \\
\text { utary inflow, and overland } \\
\text { and interflow from surround- } \\
\text { ing uplands. }\end{array}$ & $\begin{array}{l}\text { When overbank flooding of the } \\
\text { stream or river occurs, unidi- } \\
\text { rectional surface flows domi- } \\
\text { nate hydrodynamics. Surface } \\
\text { water is lost through the re- } \\
\text { turn of floodwaters to the } \\
\text { channel after flooding. May } \\
\text { have temporary standing wa- } \\
\text { ter in shallow localized de- } \\
\text { pressions until water is lost } \\
\text { through evaporation. }\end{array}$ \\
\hline
\end{tabular}

all 96 study wetlands among the regional and atypical HGM classes (Figure 4). Most of the MWs and the four previously unclassified NOWs were assigned to the atypical HGM classes. The four NOWs belonged in the atypical HGM classes due to human modifications that caused their morphology to be inconsistent with their geomorphic setting (i.e., excavation or installment of a water control structure). NOWs and MWs each make up approximately half of the wetlands of the size and type sampled in the study area.

\section{Comparison of the Landscape Profiles}

Comparison of the NOW and All Site landscape profiles reveals that NOWs and MWs currently make up different segments of the region's wetland resource and that they are not structurally equivalent (Figures 2 and 4). MWs are hydrogeomorphically different from NOWs, as most NOWs fell into the regional HGM classes (91\%), but most MWs fit the atypical classes $(75 \%)$. Riverine wetlands continue to be the largest category (Figure 4). However, two of the atypical HGM classes, in-stream-depression and depression-in-riverine-setting, now follow riverine wetlands as the types occurring most frequently, each with $20 \%$ of all the study sites. NOWs make up the bulk of wetlands in the riverine class $(81 \%)$, but the classes depression-in-riverine-setting and in-stream-depression mostly consist of MWs ( $89 \%$ of each class). Another way to look at the pattern is that $26 \%$ of all the wetlands studied are riverine NOWs, while $35 \%$ are MWs that are in-stream-depressions or depressions-in-riverine-setting. The addition of the MWs to the regional wetland resource has substantially altered the landscape profile because the MWs in the largest, atypical HGM classes make up a larger proportion of the wet- 


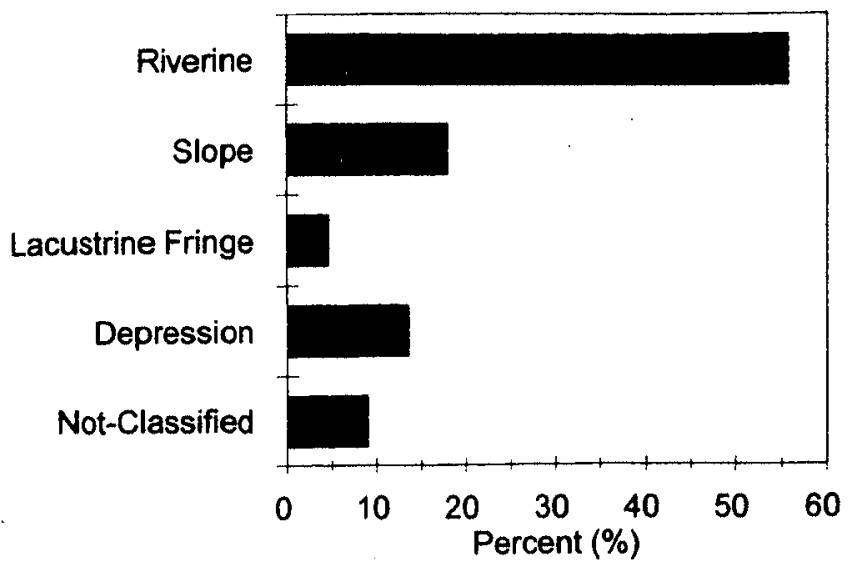

Figure 2. Landscape profile for naturally occurring wetlands (NOWs) in the Portland, Oregon metropolitan area ( $\mathrm{n}$ $=45$ ) showing the proportional distribution of NOWs among the regional hydrogeomorphic classes (riverine, slope, lacustrine fringe, and depression) and a category for the sites that could not be classified (not-classified).

lands in the region than do NOWs in the riverine class, which was probably the most common class historically (Davis 1995).

The All Site-Profile also shows an increase in the proportion of wetlands in the four HGM classes with depressional morphology (i.e., depression, in-streamdepression, depression-in-riverine-setting, and depression-in-slope-setting) (Figure 4). When wetlands with depressional morphology are combined into a depressional category, riverine wetlands no longer make up the largest proportion of the profile. Instead, wetlands with depressional morphology become the most prevalent type and make up $56 \%$ of the profile (54/96 sites), with MWs comprising a large majority (44/54 sites) of wetlands in the depressional category. Riverine wetlands are the most prevalent HGM class within the NOW-Profile and historically, but wetlands with depressional morphology have come to dominate the contemporary landscape.

\section{Comparison of Mitigation Methods}

The methods used to construct the MWs provide insight into the origin of the atypical regional HGM types and the differences between the landscape profiles. The MWs studied were constructed through creation, exchange, expansion, or some combination of exchange and expansion (Table 1). None of the MWs in our study were restorations, and only a small proportion were creations (Figure 5). A majority of all MWs were the result of exchange, the practice of converting a wetland from one type to another $(55 \%)$, and an additional $16 \%$ of the MWs involved a combination of exchange and expansion (Exp/Exch). Therefore,
$71 \%$ of the MWs were constructed through exchange of all or part of an existing wetland.

Approximately half $(8 / 15)$ of the MWs constructed through creation or expansion fall within the regional HGM classes. However, almost all the MWs resulting from exchange or a combination of expansion and exchange fall into one of the atypical classes (31/36 sites). Landscape profiles were constructed to show site conditions that existed prior to mitigation (Figure 6A) and after construction activities had occurred (Figure 6B). Prior to mitigation activities, the HGM types that occurred where MWs now exist were mostly riverine wetlands $(73 \%)$ with smaller proportions of slope, depression, and lacustrine fringe wetlands, as well as uplands (Figure 6A). This is the same pattern seen in the NOW-Profile (Figure 2) and inferred from descriptions of historic conditions (Davis 1995). Comparison of the two profiles (Figure 6A with $6 \mathrm{~B}$ ) reveals that mitigation activities have changed the landscape by converting 17 of 37 riverine wetlands to in-streamdepressions and converting another 17 to depressionsin-riverine-setting; only six riverine wetlands remained riverine after mitigation construction activities took place. Similarly, four of the five original slope wetlands were converted by mitigation to depressions-inslope-setting.

These results show that the regional atypical HGM classes are a consequence of mitigation projects being constructed within wetlands of other, naturally occurring, regional HGM classes. They also indicate that when mitigation is performed through modification of existing wetlands, changes in type, usually without natural analogues, almost always result. Thus, the wetland morphology and associated hydrodynamics that evolved in a particular landscape setting have been replaced with a hydrogeomorphic form that does not naturally occur in that setting.

\section{DISCUSSION}

Our results demonstrate the utility of using HGM classification (Brinson 1993, Smith et al. 1995) and landscape profiles (Bedford 1996) to evaluate the potential cumulative effects of resource management decisions. HGM classification is an especially appropriate approach for landscape-scale analysis because it is based on the intrinsic link between hydrology and geomorphic setting (Brinson 1993), augments other wetland classification systems (e.g., Cowardin et al. 1979), and can be accomplished relatively inexpensively using readily available, existing mapped data in combination with rapid, non-destructive field verification.

Although differences between NOWsand MWs have been widely documented (e.g., Owen 1990, Confer and Niering 1992, Eggers 1992, Holland and Ken- 
Table 3. Descriptions of the regional, atypical hydrogeomorphic (HGM) classes for wetlands in the Portland, Oregon metropolitan area. Definitions are based on principles developed by Brinson (1993) and Smith et al. (1995).

\begin{tabular}{|c|c|c|c|}
\hline HGM Class & Geomorphic Setting & Water Source & Hydrodynamics \\
\hline $\begin{array}{l}\text { Depression-in-riverine- } \\
\text { setting }\end{array}$ & $\begin{array}{l}\text { Topographic depression located } \\
\text { alongside a stream or river } \\
\text { channel. Depression was } \\
\text { formed through excavation } \\
\text { adjacent to the stream and is } \\
\text { separated from the stream } \\
\text { channel by a berm. Closed } \\
\text { contours allow the accumula- } \\
\text { tion and retention of surface } \\
\text { waters. Inlets/outlets may } \\
\text { consist of culverts, spill } \\
\text { dams, or open channels be- } \\
\text { tween the wetland and tribu- } \\
\text { taries and between the wet- } \\
\text { land and the stream. Inlets/ } \\
\text { outlets to the stream are } \\
\text { located above normal stream } \\
\text { level, preventing interchange } \\
\text { of water between the wetland } \\
\text { and the stream except during } \\
\text { storm episodes and high flow } \\
\text { conditions. }\end{array}$ & $\begin{array}{l}\text { Water is primarily from precipi- } \\
\text { tation, ground-water dis- } \\
\text { charge, and overland surface } \\
\text { flow from adjacent uplands. } \\
\text { Surface waters are often de- } \\
\text { livered through tributary cul- } \\
\text { verts and storm drains. Dur- } \\
\text { ing the rainy season, } \\
\text { subsurface hydraulic connec- } \\
\text { tions and overbank flow } \\
\text { from the stream during } \\
\text { flooding events are also pri- } \\
\text { mary sources. }\end{array}$ & $\begin{array}{l}\text { At base water levels, surface } \\
\text { waters in the wetland are sta- } \\
\text { bilized at or below the eleva- } \\
\text { tion of outlets or water con- } \\
\text { trol structures and are } \\
\text { isolated from the stream. } \\
\text { During flooding events, sur- } \\
\text { face flow from tributaries } \\
\text { may merge with streamflow } \\
\text { as the tributaries deliver wa- } \\
\text { ter through the wetland to } \\
\text { the stream and when the } \\
\text { stream overtops its banks } \\
\text { during extreme events. After } \\
\text { flooding events, surface wa- } \\
\text { ters return to the stream } \\
\text { channel until water levels in } \\
\text { the wetland fall below the } \\
\text { level of inlets/outlets. }\end{array}$ \\
\hline In-stream-depression & $\begin{array}{l}\text { Topographic depression located } \\
\text { within a stream or river } \\
\text { channel. Depression formed } \\
\text { through excavation and/or } \\
\text { damming of a portion of the } \\
\text { stream channel. The inlet } \\
\text { and outlet are the stream } \\
\text { channel or culverts contain- } \\
\text { ing the stream channel lead- } \\
\text { ing into or out of the wet- } \\
\text { land. }\end{array}$ & $\begin{array}{l}\text { Primary water source is the } \\
\text { stream channel. Wetland also } \\
\text { receives water from tributar- } \\
\text { ies (can be through culverts } \\
\text { and storm drains), overland } \\
\text { surface flow, ground-water } \\
\text { discharge, and precipitation. }\end{array}$ & $\begin{array}{l}\text { Unidirectional surface flows } \\
\text { dominate most of the year. } \\
\text { At low water, water levels } \\
\text { are regulated by the water- } \\
\text { control structure or edge of } \\
\text { the excavation. This prevents } \\
\text { surface waters from exiting } \\
\text { the wetland downstream } \\
\text { through the stream channel } \\
\text { and maintains standing water } \\
\text { within the wetland, which } \\
\text { promotes stagnant conditions. }\end{array}$ \\
\hline $\begin{array}{l}\text { Depression-in-slope- } \\
\text { setting }\end{array}$ & $\begin{array}{l}\text { Topographic depression placed } \\
\text { on sloping land where there } \\
\text { is a discharge of ground wa- } \\
\text { ter to the surface. Depression } \\
\text { has been formed through ex- } \\
\text { cavation on the hillside or at } \\
\text { its base. A berm may be } \\
\text { placed on the lower edge of } \\
\text { the depression to impound } \\
\text { water. Closed contours allow } \\
\text { accumulation of surface wa- } \\
\text { ters and maintenance of } \\
\text { ponded conditions. Inlets/out- } \\
\text { lets can include culverts and } \\
\text { storm drains. }\end{array}$ & $\begin{array}{l}\text { Primary water source is } \\
\text { groundwater or overland } \\
\text { flow from the slope wetland } \\
\text { located immediately up-gra- } \\
\text { dient from the depression. } \\
\text { Wetland also receives water } \\
\text { from precipitation and sur- } \\
\text { face flows, often delivered } \\
\text { through culverts. }\end{array}$ & $\begin{array}{l}\text { Ground water is at the surface } \\
\text { during the rainy season and } \\
\text { moves into the wetland later- } \\
\text { ally through the soil during } \\
\text { the dry season. The closed } \\
\text { contours of the depression } \\
\text { promote accumulation of wa- } \\
\text { ter and maintenance of pond- } \\
\text { ed conditions, stabilizing wa- } \\
\text { ter levels. }\end{array}$ \\
\hline
\end{tabular}




\section{A. Depression-in-riverine-setting}
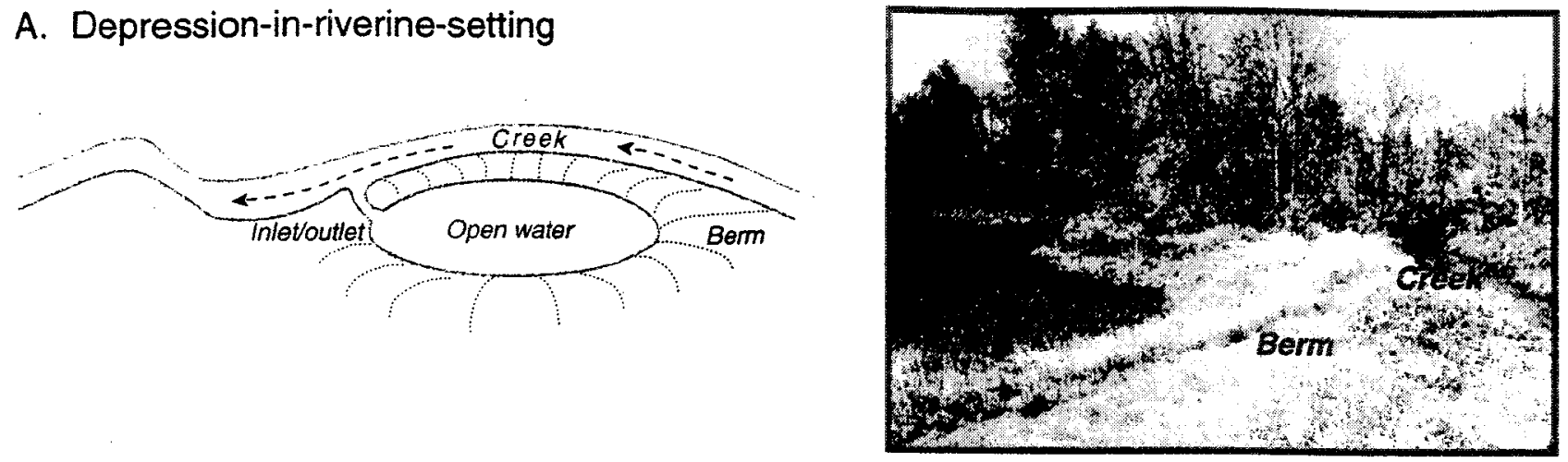

\section{B. In-stream-depression}
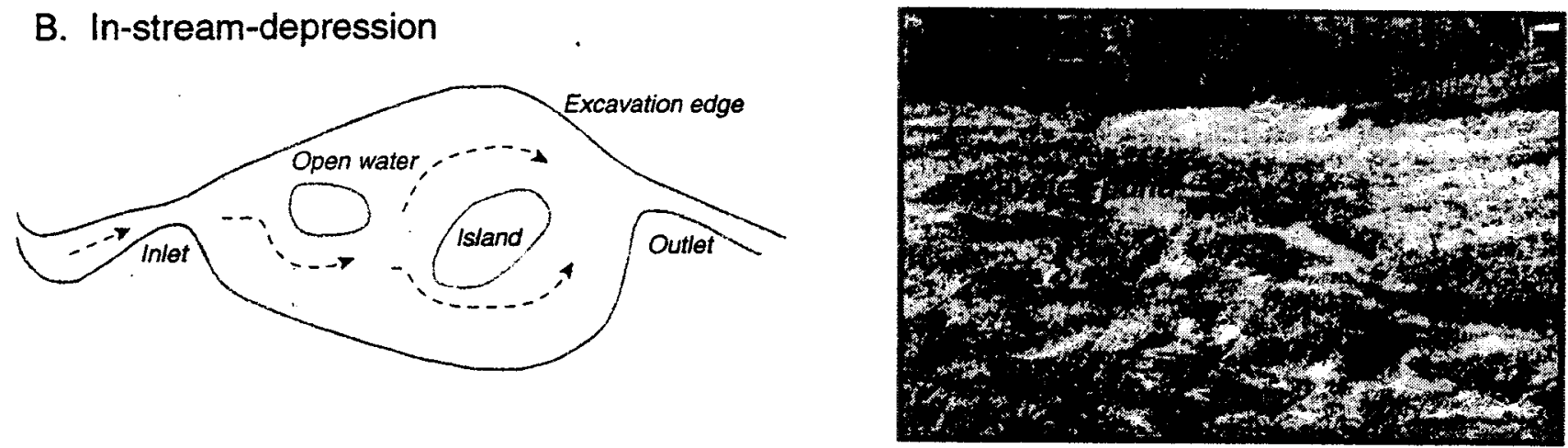

\section{Depression-in-slope-setting}
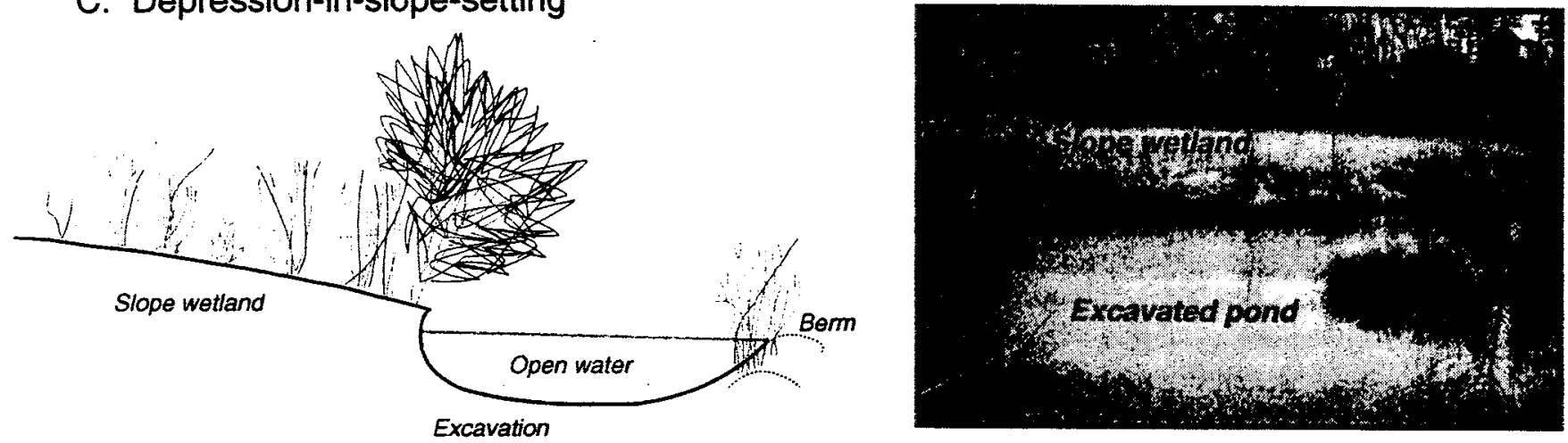

Figure 3. Diagrams and photographs of wetlands representative of the regional atypical HGM classes: A) depression-inriverine setting, B) in-stream-depression, and C) depression-in-slope-setting.

tula 1992, Kentula et al. 1992a,b, Owen and Jacobs 1992, Sifneos et al. 1992a,b, Shaich and Franklin 1995, Sibbing 1997, Cole and Brooks 1999), the cumulative effects of these differences on the resource have not been determined. Our approach illustrates how landscape profiles (Bedford 1996) can be used to characterize the distribution of functional classes of wetlands within a region and to determine the effects of regulatory decisions. Landscape profiles identify the wetland types that occur in the landscape, the geomorphic settings in which particular wetland types occur, and the relative abundance of each type. The definition of regional HGM types specific to the study area was a necessary prelude to generation of the landscape profiles. Because HGM classification is related to wetland function, comparisons of changes in the profiles for an area predict the potential ecological effects of wetland regulation at the landscape scale. 

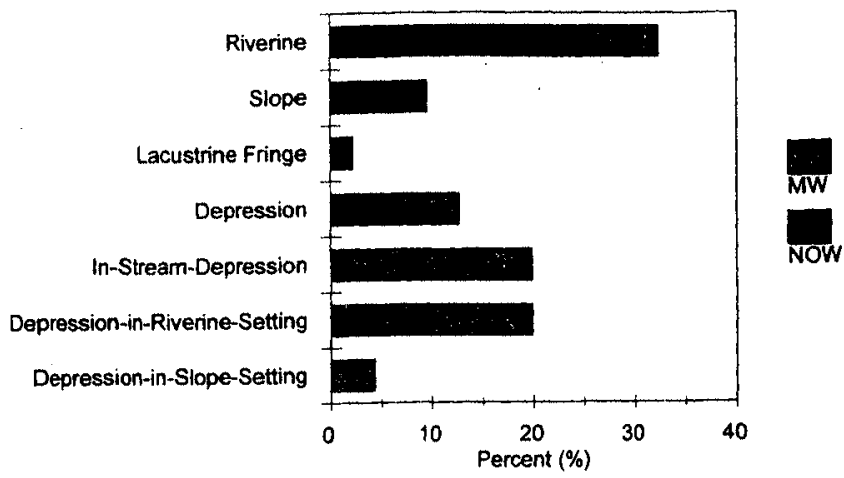

Figure 4. Landscape profile for naturally occurring wetlands (NOWs) $(\mathrm{n}=45)$ and mitigation wetlands (MWs) ( $=51$ ) in the Portland, Oregon metropolitan area (the All Site-Profile). Wetlands are distributed among the four regional hydrogeomorphic (HGM) types (riverine, slope, lacustrine fringe, and depression) and the three regional atypical HGM types (in-stream-depression, depression-in-riverine-setting, and depression-in-slope-setting).

The value of such an approach is apparent in the starkly different profiles our results show for naturally occurring wetlands (the NOW-Profile, Figure 2) as compared to that for the naturally occurring and mitigation wetlands (the All Site-Profile, Figure 4). The NOW-Profile provides a contemporary "standard" against which past and future cumulative effects of case-by-case decisions can be discerned. Because MWs are the physical manifestation of individual regulatory decisions, differences between the NOW-Profile (Figure 2) and the All Site-Profile (Figure 4) quantify the current effects of these decisions on the landscape. Our results indicate that although MWs have usually been placed within the geomorphic settings where NOWs exist, most have been designed and built with a morphology historically rare in the region ( $\mathrm{Da}$ vis 1995, Holland et al. 1995) and have a combination of setting and morphology that do not have natural analogues in the region. The end result is that management decisions have not only failed to preserve the naturally occurring landscape profile but, instead, have changed it by introducing atypical HGM types into the region. Future decisions could be improved through development of landscape profiles. Landscape profiles allow resource managers to identify changes in the abundances of HGM types and to make decisions about the efficacy of current policies and practices. By considering the relative abundance of HGM types and where they occur, wetland managers could tailor activities to be appropriate to the geomorphic settings found in the region.

In our study area, one rationale used for the construction of wetlands with depressional morphology (i.e., ponds) as mitigation projects is that ponds were

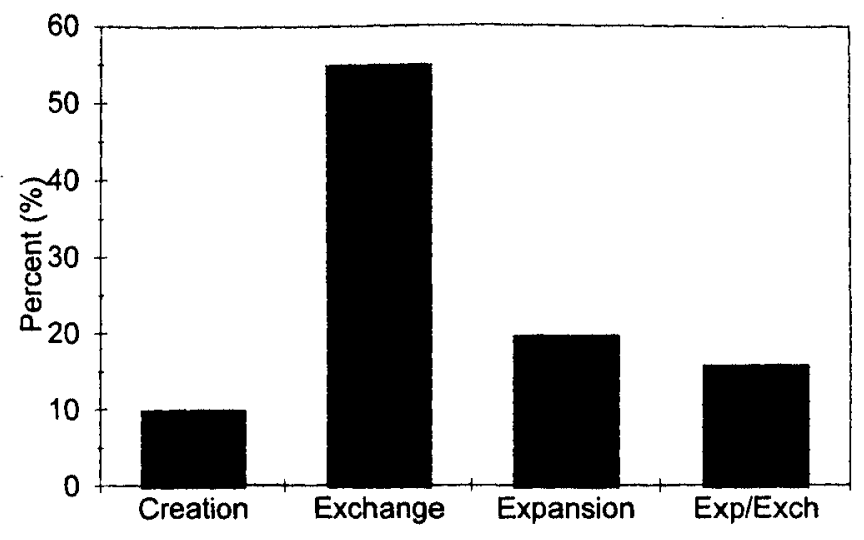

Figure 5. Distribution of mitigation wetlands (MWs) $(\mathbf{n}=$ 51) by method of construction (mitigation method). Mitigation methods used for wetlands included in this study are creation, exchange, expansion, and a combination of exchange and expansion (Exp/Exch) and are described in Table 1 .
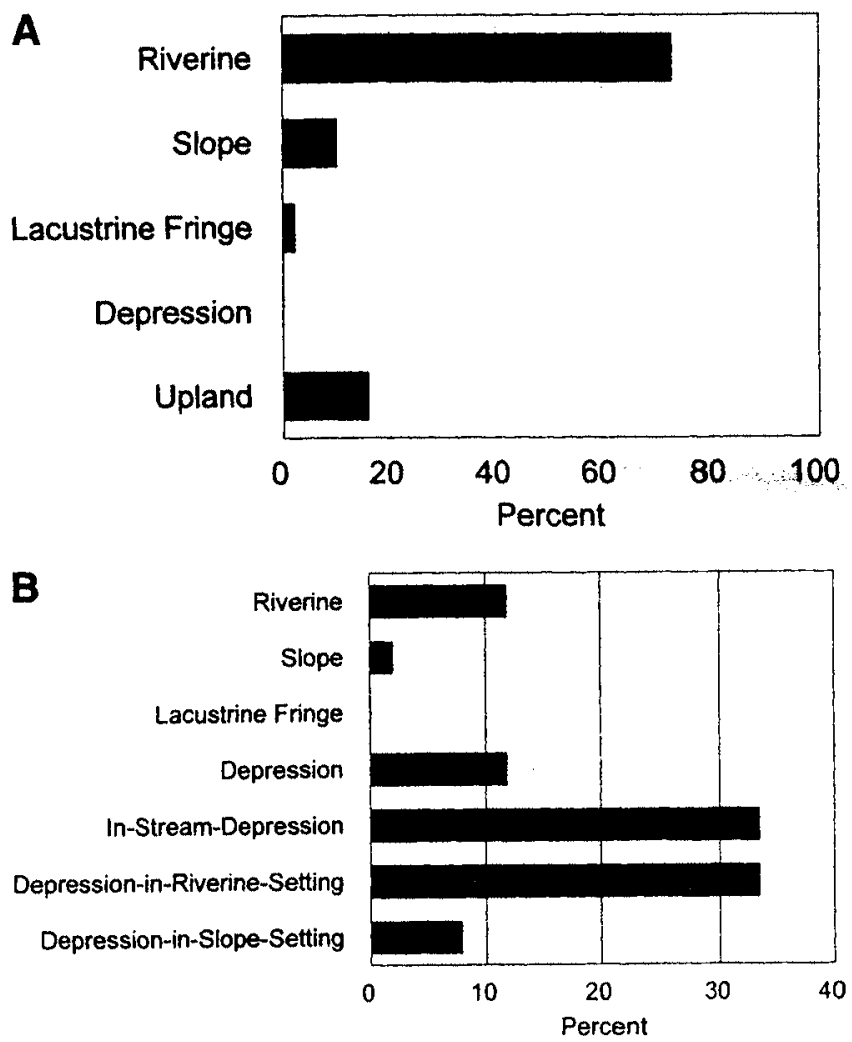

Figure 6. Distribution of mitigation wetlands (MWs) among HGM classes before and after mitigation construction activities. A) HGM classes that existed prior to mitigation actions are based on information from the National Wetland Inventory (1981/1982 aerial photography), Oregon Division of State Lands and Section 404 permit files, topographic maps, soil survey maps, and site visits. B) HGM classes existing after mitigation activities were completed are based on information from permit files and site visits. Comparison of the two graphs shows the exchange of wetland types that has occurred through mitigation activities. 
historically rare. The NOW-Profile revealed that ponds were rare because the hydrogeomorphic conditions that control the development and maintenance of depressions are uncommon in the study area. The All Site-Profile showed that regulatory decisions have been successful in reversing this rarity; through mitigation, wetlands with depressional morphology have become the most prevalent type (Figure 4). Understanding why the resource is rare and considering both positive and negative consequences of changing the relative abundances of wetland types are critical to ecologically sound management. One positive consequence of increasing the abundance of wetlands with depressional morphology may be the creation of additional habitat for particular types of waterfowl. Nevertheless, an abundance of ponds is not the norm for this region, and the native biota evolved to inhabit the types of wetlands described by the NOW-Profile. Therefore, a negative consequence of the increased abundance of wetlands in the atypical HGM classes and the concurrent decrease in the abundance of other regional HGM types may be that native organisms that evolved along with the landscape may be displaced when habitat favorable to exotic, often nuisance, species is increased. For example, as we noted earlier in this paper, the decrease in native amphibians and the concurrent proliferation of bullfrogs (Rana catesbeiana) may be tied, in part, to the increase in the relative abundance of perennially inundated systems (Nussbaum et al. 1983, Leonard et al. 1993, Kiesecker and Blaustein 1997, Kupferberg 1997).

The differences between the Now-Profile and the All Site-Profile resulted not only from the addition of atypical HGM types to the landscape but also from changes made within existing NOWs. Individual, naturally occurring wetlands are often altered by what is commonly called enhancement but, in the cases reported here, is more correctly termed exchange. Exchange accurately describes the process because what actually occurs is the on-site replacement of one wetland type by another (Figure 6). When exchange is used for mitigation, a single Section 404 decision results in the destruction of the wetland for which the permit was issued, along with the conversion of a second wetland to a different, often atypical, HGM type. This "double whammy" means that exchange explicitly does not fulfill the objective of "no-net-loss" of wetlands but, instead, ensures loss of wetland area, additional wetland disturbance, and changes in overall ecological function.

On a site-specific basis, excavating a pond within a riverine or slope wetland may appear to increase the diversity of the site. However, for the population of wetlands across the region, the practice is altering the variety of wetland types to reflect one prevailing mor- phology. An historically diverse ecosystem of different HGM types is becoming a homogenous landscape dominated by wetlands with depressional morphology.

Our research has shown that viewing the cumulative effects of regulatory decisions within a hydrogeomorphic framework (Brinson 1993, Bedford 1996) can be done effectively and inexpensively. In doing so, we have shown that wetland regulation has resulted in a major, previously unrecognized shift in hydrogeomorphic types on the landscape. While our results are important in documenting changes within a specific region, the research will ultimately be more useful in demonstrating an approach for evaluating past and future management decisions, with landscape profiles providing a tool for making better informed, regionally based decisions regarding the fate of our wetland resources.

\section{ACKNOWLEDGMENTS}

The research presented in this paper benefitted from the efforts and advice of a number of people. First, we gratefully acknowledge Barbara L. Bedford and Mark M. Brinson, whose works inspired the idea of using landscape profiles and HGM classification to examine the wetland resource in our study area. Robert $P$. Brooks and Charles A. Cole of Pennsylvania State University's Cooperative Wetlands Center generously spent hours in the field with us sharing their practical knowledge of how to apply the principles of HGM classification in "real life" situations. Staff members Kathleen A. Dwire, Cindy C. Holland, JoEllen Honea, and Teresa $\mathrm{K}$. Magee, along with $23 \mathrm{~K}-12$ teachers, collected the field data from which the site maps were generated and which provided supporting information used in this study. The staff of the Oregon Division of State Lands graciously allowed us to access their records and permit files. Finally, we thank Richard F. Ambrose, Ted L. Ernst, Charles W. Hendricks, Thomas Hruby, Phillip R. Kaufmann, Teresa K. Magee, Charles A. Rhodes, and two anonymous reviewers who provided insightful and constructive criticism of the various drafts of the manuscript. The research described in this manuscript was funded by the U.S. Environmental Protection Agency and was conducted at EPA's National Health and Environmental Effects Research Laboratory-Western Ecology Division in Corvallis, Oregon. Work was supported by contract 68 C6-0005 with Dynamac Corporation and contract 68C4-0019 with ManTech Environmental Technology, Inc. Suzanne Pierson of OAO Corporation produced Figures 1 and 3 under EPA contract 68-W5-0065, delivery order \#19. This document has been subjected to the Agency's peer and administrative review and approved for publication. Mention of trade names or 
commercial products does not constitute endorsement or recommendation for use.

\section{LITERATURE CITED}

Abbruzzese, B. and S. G. Leibowitz. 1997. A synoptic approach for assessing cumulative impacts to wetlands. Environmental Management 21:457-475.

Administrative Rules for Oregon's Removal-Fill Permit Program, OAR 141-85-005 to OAR 141-85-090. 1986. Oregon Division of State Lands, Salem, OR, USA.

Bedford, B. L. 1996. The need to define hydrologic equivalence at the landscape scale for freshwater wetland mitigation. Ecological Applications 6:57-68.

Bedford, B. L. and E. M. Preston. 1988. Developing the scientific basis for assessing cumulative effects of wetland loss and degradation on landscape functions: status, perspectives, and prospects. Environmental Management 12:751-772.

Brinson, M. M. 1993. A Hydrogeomorphic Classification for Wetlands. U.S. Army Corps of Engineers, Waterways Experiment Station, Vicksburg, MS, USA. Technical Report WRP-DE-4.

Brinson, M. M. and R. Rheinhardt. 1996. The role of reference wetlands in functional assessment and mitigation. Ecological Applications 6:69-76.

Clarke, S. E., D. White, and A. L. Schaedel. 1991. Oregon ecological regions and subregions for water quality management. Environmental Management 15:847-856.

Cole, C. A. and R. P. Brooks. 1999. A comparison of the hydrologic characteristics of natural and created mainstem floodplain wetlands in Pennsylvania. Ecological Engineering. 12:(in press).

Confer, S. R. and W. A. Niering. 1992. Comparison of created and natural freshwater emergent wetlands in Connecticut (USA). Wetlands Ecology and Management 2:143-156.

Cowardin, L. M., V. Carter, F. C. Golet, and E. T. LaRoe. 1979. Classification of wetlands and deepwater habitats of the United States. U.S. Fish and Wildlife Service, Washington, DC, USA. FWS/OBS-79/31

Dahl, T. E. and C. E. Johnson. 1991. Status and Trends of Wetlands in the Conterminous United States, Mid-1970's to Mid-1980's. U.S. Department of the Interior, Fish and Wildlife Service, Washington, DC, USA.

Davis, M. M. 1995. Endemic wetlands of the Willamette Valley, Oregon. p. 1-8. In Studies of Plant Establishment Limitations in Wetlands of the Willamette Valley, Oregon. U.S. Army Corps of Engineers, Waterways Experiment Station, Vicksburg, MS, USA. Technical Report WRP-RE-13.

Eggers, S. D. 1992. Compensatory wetland mitigation: some problems and suggestions for corrective measures. U.S. Army Corps of Engineers, St. Paul District, MN, USA.

Findlay, C. S. and J. Houlahan. 1997. Anthropogenic correlates of species richness in southeastern Ontario wetlands. Conservation Biology 11:1000-1009.

Forman, R. T. T. and M. Godron. 1986. Landscape Ecology. John Wiley and Sons, Inc. New York, NY, USA.

Gibbs, J. P. 1993. Importance of small wetlands for the persistence of local populations of wetland-associated animals. Wetlands 13: 25-31.

Gosselink, J. G. and L. C. Lee. 1989. Cumulative impact assessment in bottomland hardwood forests. Wetlands 9:83-174.

Guard, J. B. 1995. Wetland Plants of Oregon and Washington. Lone Pine Publishing, Vancouver, BC, Canada.

Gwin, S. E. and M. E. Kentula. 1990. Evaluating design and verifying compliance of wetlands created under Section 404 of the Clean Water Act in Oregon. U.S. Environmental Protection Agency, Environmental Research Laboratory, Corvallis, OR, USA. EPA $/ 600 / 3-90 / 061$

Holland, C. C., J. Honea, S. E. Gwin, and M. E. Kentula. 1995 Wetland degradation and loss in the rapidly urbanizing area of Portland, Oregon. Wetlands 15:336-345.

Holland, C. C. and M. E. Kentula. 1992. Impacts of Section 404 permits requiring compensatory mitigation on wetlands in California (USA). Wetlands Ecology and Management 2:157-169.

Kentula, M. K., R. P. Brooks, S. E. Gwin, C. C. Holland, A. D Sherman, and J. C. Sifneos. 1992a. An Approach to Improving Decision Making in Wetland Restoration and Creation. Island Press, Washington, DC, USA.

Kentula, M. E., J. C. Sifneos, J. W. Good, M. Rylko, and K. Kunz. 1992b. Trends and patterns in Section 404 permitting requiring compensatory mitigation in Oregon and Washington, USA. Environmental Management 16:109-119.

Kiesecker, J. M. and A. R. Blaustein. 1997. Population differences in responses of red-legged frogs (Rana aurora) to introduced bullfrogs. Ecology 78:1752-1760.

Kruczynski, W. L. 1990. Options to be considered in preparation and evaluation of mitigation plans. p. 555-570. In J. A. Kusler and M. E. Kentula (eds.) Wetland Creation and Restoration: The Status of the Science. Island Press, Washington, DC, USA.

Kupferberg, S. J. 1997. Bullfrog (Rana catesbeiana) invasion of a California river: the role of larval competition. Ecology 78:17361751.

Lee, L. C. and J. G. Gosselink. 1988. Cumulative impacts on wetlands: linking scientific assessments and regulatory alternatives. Environmental Management 12:591-602.

Leonard, W. P., H. A. Brown, L. L. C. Jones, K. R. McAllister, and R. M. Storm. 1993. Amphibians of Washington and Oregon. Seattle Audubon Society, Seattle, WA, USA.

Lewis, R. R. III. 1990. Wetland restoration/creation/enhancement terminology: suggestions for standardization. p. 417-422. In J. A. Kusler and M. E. Kentula (eds.) Wetland Creation and Restoration: The Status of the Science. Island Press, Washington, DC, USA.

Magee, T. K., S. E. Gwin, R. G. Gibson, C. C. Holland, J. Honea, P. W. Shaffer, J. C. Sifneos, and M. E. Kentula. 1993. Research Plan and Methods Manual for the Oregon Wetlands Study. U.S. Environmental Protection Agency, Environmental Research Laboratory, Corvallis, OR, USA. EPA/600/R-93/072.

Mitsch, W. J. and J. G. Gosselink. 1993. Wetlands. 2nd Edition. Van Nostrand Reinhold, New York, NY, USA.

National Research Council (NRC). 1995. Wetlands: Characteristics and Boundaries. National Academy Press, Washington, DC, USA.

National Research Council (NRC). 1992. Restoration of Aquatic Ecosystems. National Academy Press, Washington, DC, USA.

Nussbaum, R. A., E. D. Brodie, Jr., and R. M. Storm. 1983. Amphibians and Reptiles of the Pacific Northwest. University of Idaho Press. Moscow, ID, USA.

Omernik, J. M. 1987. Ecoregions of the conterminous United States. Annals of the Association of American Geographers 77:118-125 (map scale 1:7,500,000).

Oregon Removal-Fill Law, O.R.S. 541.605-541.695 and 541.990, and Removal or Filling in Scenic Waterways, O.R.S. 390.805$390.835,390.905$ and 390.925. 1989. Oregon Division of State Lands, Salem, OR, USA.

Oregon Wetland Inventory and Wetland Conservation Plans, O.R.S. 196.668-196.692. 1989. Oregon Division of State Lands, Salem, OR, USA.

Owen, C. R. 1990. Effectiveness of compensatory wetland mitigation in Wisconsin. Wisconsin Wetlands Association, Madison, WI, USA.

Owen, C. R. and H. M. Jacobs. 1992. Wetland protection as landuse planning: the impact of Section 404 in Wisconsin, USA. Environmental Management 16:345-353.

Race, M. S. and M. S. Fonseca. 1996. Fixing compensatory mitigation: what will it take? Ecological Applications 6:94-101.

Shaich, J. A. and K. T. Franklin. 1995. Wetland Compensatory Mitigation in Oregon: A Program Evaluation with a Focus on Portland Metro Area Projects. Oregon Division of State Lands. Salem, OR, USA.

Sibbing, J. M. 1997. Mitigation's role in wetland loss. National Wetlands Newsletter, 19:1, 17-21.

Sifneos, J. C., E. W. Cake, Jr., and M. E. Kentula. 1992a. Effects of Section 404 permitting on freshwater wetlands in Louisiana, Alabama, and Mississippi. Wetlands 12:28-36.

Sifneos, J. C., M. E. Kentula, and P. Price. 1992b. Impacts of Section 
404 permits requiring somponsatury mitigation of freshwater wet lands in rexals and Gokansas. The Texals Journal of Science 4.4 4754.85.

Smith. R. D. A. Anmatnn. C. Bartuldus, and M. M. Brinson. 1995 An Approneh for Asscising Wolland Functions Using Hydrogeomorphic Classificulion. Reference Wetlands. and Functional Indices. U.S. Ammy Corps of Engincos. Waterways Experiment Station, Vicksburg. MS, USA. Technical Report WRP-DE-9.

Tiner. R. W. Jr. 1984. Wetlands of the United State: Current status and recent trends. L.S. Fish and W'ildife Serviec, National Wetlands Luventory. Watshington. DC. LSA
Wineberg. H. 199.3. Population estimates for Oregon: July 1. 1992. Center for Poputation Research and Census, School of Urban Affairs, Portland State University, Portand. OR. USA.

Winter. T. C. 1992. A physiographic and climatic framework for hydrologic studics of wetlands. p. 127-148. In R. D. Robarts and M. L. Bothwell (eds.) Aquaric Ecosystems in Semi-Arid Regions: Implications for Resource Management. Environment Canada, Saskatoon. Saskatchewan, Canada. N.H.R.1. Symposium Series 7

Manuscript received I June 1998: revision reccived 25 November 1998: accepred 4 June 1999 